\title{
Milestones achieved in response to drought stress through
}

\section{reverse genetic approaches [version 1; peer review: 2}

\section{approved]}

\author{
Baljeet Singh (D1, Sarvjeet Kukreja², Umesh Goutam(D1 \\ ${ }^{1}$ Biotechnology, Lovely Professional University, Phagwara, Punjab, 144411, India \\ ${ }^{2}$ Department of Botany, Ch. MRM Memorial College, Sriganganagar, Rajasthan, 335804, India
}

V1 First published: 17 Aug 2018, 7:1311

https://doi.org/10.12688/f1000research.15606.1

Latest published: 17 Aug 2018, 7:1311

https://doi.org/10.12688/f1000research.15606.1

\section{Abstract}

Drought stress is the most important abiotic stress that constrains crop production and reduces yield drastically. The germplasm of most of the cultivated crops possesses numerous unknown drought stress tolerant genes. Moreover, there are many reports suggesting that the wild species of most of the modern cultivars have abiotic stress tolerant genes. Due to climate change and population booms, food security has become a global issue. To develop drought tolerant crop varieties knowledge of various genes involved in drought stress is required. Different reverse genetic approaches such as virus-induced gene silencing (VIGS), clustered regularly interspace short palindromic repeat (CRISPR), targeting induced local lesions in genomes (TILLING) and expressed sequence tags (ESTs) have been used extensively to study the functionality of different genes involved in response to drought stress. In this review, we described the contributions of different techniques of functional genomics in the study of drought tolerant genes.

\section{Keywords}

VIGS, CRISPR, TILLING, ESTs, Drought stress, Climate change, Reverse Genetics, Functional genomics

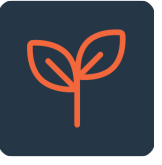

This article is included in the Agriculture, Food and Nutrition gateway.

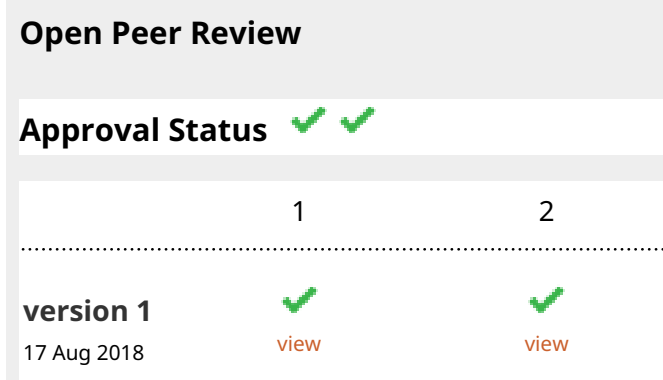

1. Elangovan Mani, Advanta India Ltd., Hyderabad, India

2. Pardeep Kumar Bhardwaj, Institute of Bioresources and Sustainable Development, Sikkim Centre, Gangtok, India

Any reports and responses or comments on the article can be found at the end of the article. 
This article is included in the Climate gateway.

Corresponding author: Umesh Goutam (umeshbiotech@gmail.com)

Author roles: Singh B: Writing - Original Draft Preparation; Kukreja S: Writing - Review \& Editing; Goutam U: Supervision, Writing Review \& Editing

Competing interests: No competing interests were disclosed.

Grant information: The author(s) declared that no grants were involved in supporting this work.

Copyright: ( 2018 Singh B et al. This is an open access article distributed under the terms of the Creative Commons Attribution License, which permits unrestricted use, distribution, and reproduction in any medium, provided the original work is properly cited.

How to cite this article: Singh B, Kukreja S and Goutam U. Milestones achieved in response to drought stress through reverse genetic approaches [version 1; peer review: 2 approved] F1000Research 2018, 7:1311 https://doi.org/10.12688/f1000research.15606.1

First published: 17 Aug 2018, 7:1311 https://doi.org/10.12688/f1000research.15606.1 


\section{Introduction}

Nowadays, global food security has becomes a major challenge due to the extreme changes to the climate and increases in the global population ${ }^{1}$. Therefore, plants are growing under various kinds of unfavourable environmental stresses such as drought, salinity, heat, cold and oxidative stresses which are retarding the growth and yield ${ }^{2,3}$. Of these, drought stress is the most predominant abiotic stress making this situation worse. Over the last decade, climate change has been increasing the frequency drought conditions and reduced the crop yield (Table 1) by affecting the basic plant growth processes such as seed germination, photosynthesis, source sink relationships, turgor pressure,

\begin{tabular}{|c|c|c|}
\hline Crop & $\begin{array}{l}\text { Yield loss } \\
\text { (approx. \%) }\end{array}$ & References \\
\hline Wheat & $\begin{array}{l}57 \\
21 \\
26\end{array}$ & $\begin{array}{l}4 \\
5 \\
6\end{array}$ \\
\hline Rice & 53-92 & 7 \\
\hline Maize & $\begin{array}{c}63-87 \\
40 \\
40\end{array}$ & $\begin{array}{l}8 \\
5 \\
6\end{array}$ \\
\hline Chickpea & $45-69$ & 9 \\
\hline Soybean & $46-71$ & 10 \\
\hline Sunflower & 60 & 11 \\
\hline Potato & 17 & 12 \\
\hline Barley & $37-41$ & 13 \\
\hline
\end{tabular}

cell division and elongation, enzyme activities, and secondary metabolites production ${ }^{14-24}$. In addition, drought can also increase the production and accumulation of reactive oxygen species (ROS) in plants which leads to oxidative stress too ${ }^{25,26}$. Several genes that express under drought conditions are involved in the regulation of all these processes and pathways. In recent years, many drought tolerant genes have been identified in major food crops and still there are numerous genes taking part in drought stress whose functions are unknown. With the help of available genomic and transcriptomic data reverse genetic approaches accelerated the investigations of gene function under different abiotic stresses ${ }^{27}$.

From the perspective of crop improvement, transgenic approaches have been successfully used in many crops. However, development of stable transgenic lines is relatively expensive, time consuming and a laborious task. Moreover, it is not successful in many cultivated crops and slows down the investigations into specific gene ${ }^{28}$. In contrast, there are several techniques available for the study of these genes which give prompt results and have other advantages over transgenic techniques for analysis of target gene(s) such as virus-induced gene silencing (VIGS), clustered regularly interspace short palindromic repeat (CRISPR)-Cas9 system, targeting induced local lesions in genomes (TILLING) and expressed sequence tags (ESTs) ${ }^{29-32}$.

\section{VIGS}

It is a simple, rapid, reliable and cost-effective post-transcriptional gene silencing (PTGS) technique for the study of endogenous genes. It is a powerful tool for the mining and study of genes involved in drought tolerance (Table 2). In VIGS a 200-400bp long fragment of the target gene is selected and cloned into a

\section{Table 2. Successfully confirmed genes via different virus-induced gene silencing (VIGS) systems.}

\begin{tabular}{|c|c|c|c|c|}
\hline Viral vector & Type & Crop & Target gene & Reference \\
\hline BSMV (Barley Stripe Mosaic Virus) & RNA virus & $\begin{array}{l}\text { Wheat } \\
\text { Barley }\end{array}$ & $\begin{array}{l}\text { TaEra1, } \\
\text { TaSal1 } \\
\text { TaBTF3 } \\
\text { TaPGR5 } \\
\text { TdAtg8 } \\
\text { HvHVA1 } \\
\text { HvDhn6 } \\
\text { HvEXPB7 } \\
\text { HvATG6 }\end{array}$ & $\begin{array}{l}33 \\
33 \\
34 \\
35 \\
36 \\
37 \\
37 \\
38 \\
39\end{array}$ \\
\hline TRV (Tobacco Rattle Virus) & RNA virus & $\begin{array}{c}\text { Tomato } \\
\text { Pyrus betulaefolia } \\
\text { Chili pepper } \\
\text { Cotton }\end{array}$ & $\begin{array}{c}\text { Sllea4 } \\
\text { SpMPK1, } \\
\text { SpMPK2, } \\
\text { SpMPK3 } \\
\text { SIMPK4 } \\
\text { SISR1L } \\
\text { SIJUB1 } \\
\text { PbrMYB21 } \\
\text { CaPO2 } \\
\text { CaMLO2 } \\
\text { CaAIR1 } \\
\text { CaAIP1 } \\
\text { CaWDP1 } \\
\text { GhMKK3 } \\
\text { GhWRKY27a }\end{array}$ & $\begin{array}{l}40 \\
41 \\
41 \\
41 \\
42 \\
43 \\
44 \\
45 \\
46 \\
47 \\
48 \\
49 \\
50 \\
51 \\
52\end{array}$ \\
\hline TYLCCNV (Tomato Yellow Leaf Curl China Virus) & DNA virus & Tomato & SIGRX1 & 53 \\
\hline CLCrV(Cotton Leaf Crumple Virus) & DNA virus & Cotton & GhNAC79 & 54 \\
\hline
\end{tabular}


viral vector which infects the plant and triggers the silencing of that particular gene ${ }^{29,55}$. For efficient gene silencing the selection of the target fragment is very crucial. This technology can be used for forward and reverse genetics for both monocotyledonous and dicotyledonous plants ${ }^{56,57}$. There is no requirement of stable plant transformants in VIGS technology ${ }^{58}$. Moreover, a number of different genes can be studied simultaneously and a specific target can also be silenced individually through this technology ${ }^{59,60}$. Many VIGS vectors have been developed for different crops by modifying plant viruses and have been used successfully for the functional study of genes expressed under drought stress ${ }^{61-64}$. These VIGS vectors along with the target gene can be inoculated into the plants by different methods such as agrodrench, needleless syringe inoculation, agro inoculation, prick inoculation, and biolistic inoculation ${ }^{29,65}$.

Plants have adopted many molecular mechanisms to withstand different abiotic stress, and a number of stress related genes get stimulated under stress conditions ${ }^{66,67}$. Among them, MAPKs (Mitogen Activated Protein Kinases) are the most important enzymes for the plant growth and development and also play an important role in signal transduction under extreme conditions $^{68-72}$. The role of different MAPKs under drought stress has been studied through VIGS technology. The silencing of genes SpMAPK1, SpMAPK2, SpMAPK3 in Solanum pimpinellifolium, SIMPK in Solanum Lycopersicum and GhMKK3 in Gossypium hirsutum reduced the drought tolerance in silenced plants $^{41,42,51}$.

In addition, various transcriptional factors regulate the plants behaviour in response to environmental conditions ${ }^{73}$. The WRKYs transcription factors play crucial role in the plant development under drought stress $^{74}$. In cotton the VIGS of GhWRKY27a enhanced the tolerance against drought stress $^{52}$. Further, another family of transcriptional factor, NAC, plays an important role under drought ${ }^{75}$. Silencing of the GhNAC79 and JUB1 genes in cotton and tomato respectively made the plants more sensitive to drought ${ }^{44,54}$. In addition, PbrMYB21 gene belonging to MYB family of transcription factors (TFs) studied in Pyrus betulaefolia. The PbrMYB21 silenced plants exhibited decreased drought tolerance in comparison to control plants ${ }^{45}$. Beside these, SR/CAMTA proteins from a small family of TFs and silencing of SISRIL and SlGRX1 genes from this resulted in decreased tolerance against drought stress in tomato ${ }^{43,53}$.

Beside these, autophagy, a protein degradation process induced in plants in response to environmental stimuli, has been reported to be involved due to the involvement of autophagy-related genes (ATG) under drought stress ${ }^{76-78}$. The ATG8 gene in wheat and ATG6 and its orthologs get induced in wheat, rice and barley in response to multiple abiotic stresses. Barley stripe mosaic virus (BSMV) based VIGS system was used for their functionality under drought stress. The results indicated the active participation of $A T G$ genes in various survival mechanisms used by plants under drought ${ }^{36,39}$. In spite of these, many drought tolerant genes have been reported in weeds and also wild species of major cultivars. For instance, ApDRI15 gene in a weed named, Alternanthera philoxeroidsi has been identified as a drought tolerant gene through VIGS ${ }^{79}$.

\section{Expressed sequence tags (ESTs)}

It is a sequence based technique that can be used to identify or study genes. ESTs can be generated from cDNA libraries ${ }^{80}$. Functional studies of specific genes using this technique, can provide results in a cost-effective manner ${ }^{81}$. Large scale EST sequencing has been performed in various crops and in several crops it is in progress. Millions of ESTs of different crops are available at Expressed Sequence Tags Database of National Center of Biotechnology Information. To identify drought stress responsive genes, first cDNA libraries are developed from plants growing under stressed conditions or from drought challenged tissues of drought responsive genotypes. Then by sequencing the clones ESTs can be identified ${ }^{80,82}$. ESTs provide high quality transcripts for investigation of genes as functional markers under stress conditions. During the last two decades, drought responsive genes have been identified and studied by ESTs in a number of crops such as common beans ${ }^{83}$, barley ${ }^{84}$, chickpea ${ }^{85-88}$, sorghum $^{89,90}$, rice ${ }^{91-94}$, Camelina sativa ${ }^{95}$, wheat ${ }^{96,97}$ Kodo millet $^{98}$, pearl millet ${ }^{99,100}$, sweet potato ${ }^{101}$, rapeseed $^{102}$, Peanut ${ }^{103}$, and Ammopiptanthus mongolicus ${ }^{104}$. Analysis by BLASTX or qRT-PCR can be performed to find the most promising $\mathrm{ESTs}^{82}$.

\section{TILLING}

With the advancements in high-throughput techniques genomes of a large number of crops are available now which present a number of new opportunities for the application of traditional mutation based reverse genetic techniques ${ }^{105}$. TILLING is a nontransgenic method used to study allelic variations in the target gene in a mutant population and the effect of the mutant gene is studied from the changes in plant phenotypes ${ }^{28,106,107}$. It is a quick and comparatively cheap method for the screening of single nucleotide polymorphisms (SNP) in the target sequence. These point mutations in the target genes can be identified by $\mathrm{PCR}^{105,108}$. Moreover, this technique is applicable to any plant species whose genome sequence is available, regardless of its ploidy levels. In TILLING, to induce mutations in plant genome chemical mutagens are used that generated random mutations ${ }^{105}$. In most of the experiments, to generate the TILLING population ethymethansulfonate (EMS) is used as a mutagen ${ }^{30}$. However, to study the polymorphism developed, due to environmental conditions, a modified technique called as EcoTILLING has been developed. It seems a more promising strategy to study the genes related to abiotic stresses ${ }^{109,110}$.

\section{CRISPR Technology}

CRISPR (Clustered Regularly Interspace Short Palindromic Repeat)/ CRISPR-associated nuclease protein (Cas) 9 technology based upon plant antiviral defense mechanisms, offered various new opportunities for researchers. It is relatively simple, easy, less cytotoxic and very efficient targeted genome editing technology in comparison to traditional techniques used for the same purpose ${ }^{111,112}$. CRISPR/CAS9 based gene editing technology has become common practice in various labs. It involves the use of the CAS9 endonuclease, originally derived from Streptococcus pyogenes, and a guide RNA which leads CAS9 to the target sequence working together and generate double stranded DNA breaks which are later repaired by the error prone non-homologous end joining (NHEJ) method or by the homology directed repair (HDR) pathway ${ }^{113,114}$. Recently, this technology 
has been used extensively for crop improvement ${ }^{31,115-120}$. This system has been successfully used to study the genes involved in drought stress (Table 3) in model plant Arabidopsis $^{121}$ and also in a number of crops such as soybean, maize $^{114,122}$, rice $^{123}$, tomato $^{124}$.

\section{Conclusion and future perspectives}

Severe droughts are becoming more common every year and are reducing crop yield considerably. There is an urgent need for

\section{Table 3. Recent examples of drought associated genes studied by clustered regularly interspace short palindromic repeat (CRISPR)/Cas9.}

\begin{tabular}{|c|c|c|c|}
\hline Sr. No. & Crop & Gene Name & Reference \\
\hline 1. & Arabidopsis & mir169a & 113 \\
\hline 2. & Arabidopsis & UGT79B2,UGT79B3 & 121 \\
\hline 3. & Maize & ARGOS8 & 114 \\
\hline 4. & Tomato & slmapk3 & 124 \\
\hline 5. & Arabidopsis, Poplar & PtoMYB216 & 125 \\
\hline 6. & Rice & OsSAPK2 & 123 \\
\hline
\end{tabular}

drought tolerant varieties. Breeding and transgenic approaches could solve this problem but the knowledge of molecular mechanisms and genes taking part in drought tolerance is essential. Several reverse genetic techniques have proved their potential in many crops and some are still evolving. During the last decade, the genomes of several crops were successfully sequenced, various new VIGS systems have been developed for different crops $^{126-131}$ and CRISPR has become the most powerful tool for genome editing ${ }^{132-134}$. Thus, these techniques can play a pivotal role in crop improvement and can contribute highly in the development of drought tolerant varieties.

\section{Data availability}

No data are associated with this article

\section{Competing interests}

No competing interests were disclosed.

\section{Grant information}

The author(s) declared that no grants were involved in supporting this work.
1. Lesk C, Rowhani P, Ramankutty N: Influence of extreme weather disasters on global crop production. Nature. 2016; 529(7584): 84-7. PubMed Abstract | Publisher Full Text

2. Nouri MZ, Moumeni A, Komatsu S: Abiotic Stresses: Insight into Gene Regulation and Protein Expression in Photosynthetic Pathways of Plants. Int $J$ Mol Sci. 2015; 16(9): 20392-416. PubMed Abstract | Publisher Full Text | Free Full Text

3. Mickelbart MV, Hasegawa PM, Bailey-Serres J: Genetic mechanisms of abiotic stress tolerance that translate to crop yield stability. Nat Rev Genet. 2015; 16(4): 237-51.

PubMed Abstract | Publisher Full Text

4. Balla K, Rakszegi M, Li Z, et al.: Quality of winter wheat in relation to heat and drought shock after anthesis. Czech J Food Sci. 2011; 29(2): 117-28. Publisher Full Text

5. Fahad S, Bajwa AA, Nazir U, et al:: Crop Production under Drought and Heat Stress: Plant Responses and Management Options. Front Plant Sci. 2017; 8: 1147.

PubMed Abstract | Publisher Full Text | Free Full Text

6. Daryanto S, Wang L, Jacinthe PA: Global Synthesis of Drought Effects on Maize and Wheat Production. PLOS One. 2016; 11(5): e0156362. PubMed Abstract | Publisher Full Text | Free Full Text

7. Lafitte HR, Yongsheng G, Yan S, et al.: Whole plant responses, key processes, and adaptation to drought stress: the case of rice. J Exp Bot. 2007; 58(2): $169-75$.

PubMed Abstract | Publisher Full Text

8. Kamara AY, Menkir A, Badu-Apraku B, et al: The influence of drought stress on growth, yield and yield components of selected maize genotypes. J Agric Sci. 2003; 141(1): 43-50. Publisher Full Text

9. Nayyar H, Kaur S, Singh S, et al:: Differential sensitivity of Desi (small-seeded) and Kabuli (large-seeded) chickpea genotypes to water stress during seed filling: Effects on accumulation of seed reserves and yield. $J$ Sci Food Agric. 2006; 86(13): 2076-82. Publisher Full Text

10. Samarah $\mathrm{NH}$, Mullen RE, Cianzio SR, et al: Dehydrin-like proteins in soybean seeds in response to drought stress during seed filling. Crop Sci. 2006; 46(5): 2141-50.

Publisher Full Text

11. Mazahery-Laghab $\mathrm{H}$, Nouri $\mathrm{F}$, et al:: Effects of the reduction of drought stress using supplementary irrigation for sunflower (Helianthus annuus) in dry farming conditions. Pajouheshva Sazandegi Agron Hortic. 2003; 59: 81-6. Reference Source

12. Deblonde PMK, Ledent JF: Effects of moderate drought conditions on green leaf number, stem height, leaf length and tuber yield of potato cultivars. Eur $J$ Agron. 2001; 14(1): 31-41. Publisher Full Text

13. Jamieson PD, Martin RJ, Francis GS: Drought influences on grain yield of barley, wheat, and maize. New Zeal J Crop Hortic Sci. 1995; 23(1): 55-66. Publisher Full Text

14. Basu S, Ramegowda V, Kumar A, et al:: Plant adaptation to drought stress [version 1; referees: 3 approved]. F1000Res. 2016; 5: pii: F1000 Faculty Rev1554. PubMed Abstract | Publisher Full Text | Free Full Text

15. Tietjen B, Schlaepfer DR, Bradford JB, et al:: Climate change-induced vegetation shifts lead to more ecological droughts despite projected rainfall increases in many global temperate drylands. Glob Chang Biol. 2017; 23(7): 2743-54. PubMed Abstract | Publisher Full Text

16. Flexas J, Bota J, Loreto F, et al:: Diffusive and metabolic limitations to photosynthesis under drought and salinity in $\mathrm{C}_{3}$ plants. Plant Biol (Stuttg). 2004; 6(3): 269-79.

PubMed Abstract | Publisher Full Text

17. Lobell DB, Schlenker W, Costa-Roberts J: Climate trends and global crop production since 1980. Science. 2011; 333(6042): 616-20. PubMed Abstract | Publisher Full Text

18. Si C, Zhang JY, Xu HC: [Advances in studies on growth metabolism and response mechanisms of medicinal plants under drought stress]. Zhongguo Zhong Yao Za Zhi. 2014; 39(13): 2432-7. PubMed Abstract

19. Yordanov I, Velikova V, Tsonev T: Plant responses to drought, acclimation, and stress tolerance. Photosynthetica. 2000; 38(2): 171-86. Publisher Full Text

20. Barnabás $\mathrm{B}$, Jäger $\mathrm{K}$, Fehér $\mathrm{A}$ : The effect of drought and heat stress on reproductive processes in cereals. Plant Cell Environ. 2008; 31(1): 11-38. PubMed Abstract | Publisher Full Text

21. Kaya MD, Okçu G, Atak M, et al:: Seed treatments to overcome salt and drought stress during germination in sunflower (Helianthus annuus L.). Eur J Agron. 2006; 24(4): 291-5

Publisher Full Text 
22. Farooq M, Wahid A, Kobayashi N, et al.: Plant drought stress: effects, mechanisms and management. Agron Sustain Dev. 2009; 29(1): 185-212. Publisher Full Text

23. Hussain M, Malik MA, Farooq M, et al.: Improving drought tolerance by exogenous application of glycinebetaine and salicylic acid in sunflower. J Agron Crop Sci. 2008; 194(3): 193-9.

Publisher Full Text

24. Praba ML, Cairns JE, Babu RC, et al:: Identification of physiological traits underlying cultivar differences in drought tolerance in rice and wheat. $J$ Agron Crop Sci. 2009; 195(1): 30-46.

Publisher Full Text

25. Pastori GM, Foyer $\mathrm{CH}$ : Common components, networks, and pathways of cross-tolerance to stress. The central role of "redox" and abscisic acidmediated controls. Plant Physiol. 2002; 129(2): 460-8. PubMed Abstract | Publisher Full Text | Free Full Text

26. Nagahatenna DS, Langridge $P$, Whitford R: Tetrapyrrole-based drought stress signalling. Plant Biotechnol J. 2015; 13(4): 447-59. PubMed Abstract | Publisher Full Text | Free Full Text

27. Azevedo $\mathrm{H}$, Silva-Correia J, Oliveira J, et al:: A strategy for the identification of new abiotic stress determinants in Arabidopsis using web-based data mining and reverse genetics. OMICS. 2011; 15(12): 935-47. PubMed Abstract | Publisher Full Text

28. Slade AJ, Knauf VC: TILLING moves beyond functional genomics into crop improvement. Transgenic Res. 2005; 14(2): 109-15. PubMed Abstract | Publisher Full Text

29. Senthil-Kumar M, Mysore KS: Tobacco rattle virus-based virus-induced gene silencing in Nicotiana benthamiana. Nat Protoc. 2014; 9(7): 1549-62. PubMed Abstract | Publisher Full Text

30. Tadele Z: Drought Adaptation in Millets. In: Abiotic and Biotic Stress in Plants - Recent Advances and Future Perspectives. 2016 Publisher Full Text

31. Khatodia S, Bhatotia K, Passricha N, et al.: The CRISPR/Cas Genome-Editing Tool: Application in Improvement of Crops. Front Plant Sci. 2016; 7: 506. PubMed Abstract | Publisher Full Text | Free Full Text

32. Mohanta TK, Bashir T, Hashem A, et al.: Genome Editing Tools in Plants. Genes (Basel). 2017; 8(12): pii: E399.

PubMed Abstract | Publisher Full Text | Free Full Text

33. Manmathan $\mathrm{H}$, Shaner D, Snelling J, et al:: Virus-induced gene silencing of Arabidopsis thaliana gene homologues in wheat identifies genes conferring improved drought tolerance. J Exp Bot. 2013; 64(5): 1381-92. PubMed Abstract | Publisher Full Text | Free Full Text

34. Kang G, Li G, Ma H, et al.: Proteomic analysis on the leaves of TaBTF3 gene virus-induced silenced wheat plants may reveal its regulatory mechanism. J Proteomics. 2013; 83: 130-43.

PubMed Abstract | Publisher Full Text

35. Wang $\mathrm{Y}, \mathrm{He} \mathrm{X}$, Ma W, et al:: Wheat PROTON GRADIENT REGULATION 5 is involved in tolerance to photoinhibition. J Integr Agric. 2014; 13(6): 1206-15. Publisher Full Text

36. Kuzuoglu-Ozturk D, Cebeci Yalcinkaya O, Akpinar BA, et al: Autophagy-related gene, TdAtg8, in wild emmer wheat plays a role in drought and osmotic stress response. Planta. 2012; 236(4): 1081-92.

PubMed Abstract | Publisher Full Text

37. Liang J, Deng $\mathrm{G}$, Long $\mathrm{H}$, et al:: Virus-induced silencing of genes encoding LEA protein in Tibetan hulless barley (Hordeum vulgare ssp. vulgare) and their relationship to drought tolerance. Mol Breed. 2012; 30(1): 441-51. Publisher Full Text

38. He X, Zeng J, Cao $\mathrm{F}$, et al: HvEXPB a novel $\beta$-expansin gene revealed by the root hair transcriptome of Tibetan wild barley, improves root hair growth under drought stress. J Exp Bot. 2015; 66(22): 7405-19. PubMed Abstract | Publisher Full Text | Free Full Text

39. Zeng X, Zeng Z, Liu C, et al:: A barley homolog of yeast ATG6 is involved in multiple abiotic stress responses and stress resistance regulation. Plant Physiol Biochem. 2017; 115: 97-106.

PubMed Abstract | Publisher Full Text

40. Senthil-Kumar M, Udayakumar M: High-throughput virus-induced gene-silencing approach to assess the functional relevance of a moisture stress-induced cDNA homologous to lea4. J Exp Bot. 2006; 57(10): 2291-302. PubMed Abstract | Publisher Full Text

41. Li C, Yan JM, Li YZ, et al:: Silencing the SpMPK1, SpMPK2, and SpMPK3 genes in tomato reduces abscisic acid-mediated drought tolerance. Int $\mathrm{J} \mathrm{Mol} \mathrm{SCl}$ 2013; 14(11): 21983-96.

PubMed Abstract | Publisher Full Text | Free Full Text

42. Virk N, Liu B, Zhang H, et al:: Tomato SIMPK4 is required for resistance against Botrytis cinerea and tolerance to drought stress. Acta Physiol Plant. 2013; 35(4): 1211-21. Publisher Full Text

43. Li X, Huang L, Zhang Y, et al:: Tomato SR/CAMTA transcription factors SISR1 and SISR3L negatively regulate disease resistance response and SISR1L positively modulates drought stress tolerance. BMC Plant Biol. 2014; 14(1): 286. PubMed Abstract | Publisher Full Text | Free Full Text

44. Thirumalaikumar VP, Devkar V, Mehterov N, et al:: NAC transcription factor JUNGBRUNNEN1 enhances drought tolerance in tomato. Plant Biotechnol J. 2018; 16(2): 354-366.

PubMed Abstract | Publisher Full Text | Free Full Text
45. Li K, Xing C, Yao Z, et al.: PbrMYB21, a novel MYB protein of Pyrus betulaefolia, functions in drought tolerance and modulates polyamine levels by regulating arginine decarboxylase gene. Plant Biotechnol J. 2017; 15(9): 1186-203. PubMed Abstract | Publisher Full Text | Free Full Text

46. Choi HW, Hwang BK: The pepper extracellular peroxidase $\mathrm{CaPO} 2$ is required for salt, drought and oxidative stress tolerance as well as resistance to fungal pathogens. Planta. 2012; 235(6): 1369-82.

PubMed Abstract | Publisher Full Text

47. Lim CW, Lee SC: Functional roles of the pepper MLO protein gene, CaMLO2, in abscisic acid signaling and drought sensitivity. Plant Mol Biol. 2014; 85(1-2): $1-10$.

PubMed Abstract | Publisher Full Text

48. Park C, Lim CW, Baek W, et al.: RING Type E3 Ligase CaAIR1 in Pepper Acts in the Regulation of ABA Signaling and Drought Stress Response. Plant Cell Physiol. 2015; 56(9): 1808-19.

PubMed Abstract | Publisher Full Text

49. Park C, Lim CW, Lee SC: The pepper RING-Type E3 ligase, CaAIP1, functions as a positive regulator of drought and high salinity stress responses. Plant Cell Physiol. 2016; 57(10): 2202-12.

PubMed Abstract | Publisher Full Tex

50. Park C, Lim WC, Baek W, et al:: The pepper WPP domain protein, CaWDP1, acts as a novel negative regulator of drought stress via ABA signaling. Plant Cell Physiol. 2017; 58(4): 779-88.

PubMed Abstract | Publisher Full Tex

51. Wang C, Lu W, He X, et al.: The Cotton Mitogen-Activated Protein Kinase Kinase 3 Functions in Drought Tolerance by Regulating Stomatal Responses and Root Growth. Plant Cell Physiol. 2016; 57(8): 1629-42. PubMed Abstract | Publisher Full Text

52. Yan Y, Jia H, Wang F, et al.: Overexpression of GhWRKY27a reduces tolerance to drought stress and resistance to Rhizoctonia solani infection in transgenic Nicotiana benthamiana. Front Physiol. 2015; 6: 265.

PubMed Abstract | Publisher Full Text | Free Full Text

53. Guo $\mathrm{Y}$, Huang $\mathrm{C}, \mathrm{Xie} \mathrm{Y}$, et al:: A tomato glutaredoxin gene SIGRX1 regulates plant responses to oxidative, drought and salt stresses. Planta. 2010; 232(6): 1499-509.

PubMed Abstract | Publisher Full Text

54. Guo Y, Pang C, Jia X, et al.: An NAM Domain Gene, GhNAC79, Improves Resistance to Drought Stress in Upland Cotton. Front Plant Sci. 2017; 8: 1657. PubMed Abstract | Publisher Full Text | Free Full Text

55. Tasaki K, Terada H, Masuta C, et al:: Virus-induced gene silencing (VIGS) in Lilium leichtlinii using the Cucumber mosaic virus vector. Plant Biotechnol. 2016; 33(5): 373-81. Publisher Full Text

56. Ramegowda V, Mysore KS, Senthil-Kumar M: Virus-induced gene silencing is a versatile tool for unraveling the functional relevance of multiple abiotic-stressresponsive genes in crop plants. Front Plant Sci. 2014; 5: 323. PubMed Abstract | Publisher Full Text | Free Full Text

57. Becker A, Lange M: VIGS--genomics goes functional. Trends Plant Sci. 2010; 15(1): 1-4.

PubMed Abstract | Publisher Full Text

58. Sahu PP, Puranik S, Khan M, et al.: Recent advances in tomato functional genomics: utilization of VIGS. Protoplasma. 2012; 249(4): 1017-27. PubMed Abstract | Publisher Full Text

59. Purkayastha A, Dasgupta I: Virus-induced gene silencing: a versatile tool for discovery of gene functions in plants. Plant Physiol Biochem. 2009; 47(11-12): 967-76.

PubMed Abstract | Publisher Full Text

60. Fernandez-Pozo N, Rosli HG, Martin GB, et al:: The SGN VIGS tool: user-friendly software to design virus-induced gene silencing (VIGS) constructs for functional genomics. Mol Plant. 2015; 8(3): 486-8.

PubMed Abstract | Publisher Full Text

61. Ratcliff F, Martin-Hernandez AM, Baulcombe DC, et al:: Technical Advance. Tobacco rattle virus as a vector for analysis of gene function by silencing. Plant J. 2001; 25(2): 237-45.

PubMed Abstract | Publisher Full Text

62. Robertson D: VIGS vectors for gene silencing: many targets, many tools. Annu Rev Plant Biol. 2004; 55(1): 495-519. PubMed Abstract | Publisher Full Text

63. Igarashi A, Yamagata $\mathrm{K}$, Sugai T, et al: Apple latent spherical virus vectors for reliable and effective virus-induced gene silencing among a broad range of plants including tobacco, tomato, Arabidopsis thaliana, cucurbits, and legumes. Virology. 2009; 386(2): 407-16. PubMed Abstract | Publisher Full Text

64. Lange M, Yellina AL, Orashakova S, et al.: Virus-induced gene silencing (VIGS) in plants: an overview of target species and the virus-derived vector systems. Methods Mol Biol. 2013; 975: 1-14. PubMed Abstract | Publisher Full Text

65. Corbin C, Lafontaine F, Sepúlveda LJ, et al:: Virus-induced gene silencing in Rauwolfia species. Protoplasma. 2017; 254(4): 1813-8.

PubMed Abstract | Publisher Full Text

66. Gao JP, Chao DY, Lin HX: Toward Understanding Molecular Mechanisms of Abiotic Stress Responses in Rice. Rice. 2008; 1(1): 36-51. Publisher Full Text

67. Shivani, Dwivedi DK, Husain R, et al.: Physiological, Morphological and 
Molecular Mechanisms for Drought Tolerance in Rice. Int J Curr Microbiol Appl Sci. 2017; 6(7): 4160-73.

Publisher Full Text

68. Ara H, Sinha AK: Conscientiousness of mitogen activated protein kinases in acquiring tolerance for abiotic stresses in plants. Proc Indian Natl Sci Acad. 2014; 80(2): 211-9.

Reference Source

69. Nakagami $\mathrm{H}$, Pitzschke $\mathrm{A}$, Hirt $\mathrm{H}$ : Emerging MAP kinase pathways in plant stress signalling. Trends Plant Sci. 2005; 10(7): 339-46. PubMed Abstract | Publisher Full Text

70. Pitzschke A, Schikora A, Hirt H: MAPK cascade signalling networks in plant defence. Curr Opin Plant Biol. 2009; 12(4): 421-6. PubMed Abstract | Publisher Full Text

71. Zhang S, Klessig DF: MAPK cascades in plant defense signaling. Trends Plant Sci. 2001; 6(11): 520-7.

PubMed Abstract | Publisher Full Text

72. Romeis T: Protein kinases in the plant defence response. Curr Opin Plant Biol. 2001; 4(5): 407-14.

PubMed Abstract | Publisher Full Text

73. Guo R, Yu F, Gao Z, et al:: GhWRKY3, a novel cotton (Gossypium hirsutum L.) WRKY gene, is involved in diverse stress responses. Mol Biol Rep. 2011; 38(1) 49-58.

PubMed Abstract | Publisher Full Text

74. Zhang $\mathrm{T}$, Huang L, Wang $\mathrm{Y}$, et al.: Differential transcriptome profiling of chilling stress response between shoots and rhizomes of Oryza longistaminata using RNA sequencing. PLoS One. 2017; 12(11): e0188625. PubMed Abstract | Publisher Full Text | Free Full Text

75. Nuruzzaman M, Sharoni AM, Kikuchi S: Roles of NAC transcription factors in the regulation of biotic and abiotic stress responses in plants. Front Microbiol. 2013; 4: 248 .

PubMed Abstract | Publisher Full Text | Free Full Text

76. Liu Y, Xiong Y, Bassham DC: Autophagy is required for tolerance of drought and salt stress in plants. Autophagy. 2009; 5(7): 954-63. PubMed Abstract | Publisher Full Text

77. Nolan TM, Brennan B, Yang M, et al.: Selective Autophagy of BES1 Mediated by DSK2 Balances Plant Growth and Survival. Dev Cell. 2017; 41(1): 33-46.e7. PubMed Abstract | Publisher Full Text | Free Full Text

78. Wang W, Xu M, Wang G, et al.: Autophagy: An Important Biological Process That Protects Plants from Stressful Environments. Front Plant Sci. 2017; 7: 2030.

PubMed Abstract | Publisher Full Text | Free Full Text

79. Bai C, Wang P, Fan Q, et al:: Analysis of the Role of the Drought-Induced Gene DRI15 and Salinity-Induced Gene SI1 in Alternanthera philoxeroides Plasticity Using a Virus-Based Gene Silencing Tool. Front Plant Sci. 2017; 8: 1579. PubMed Abstract | Publisher Full Text | Free Full Text

80. Blair MW, Hurtado N, Chavarro CM, et al.: Gene-based SSR markers for common bean (Phaseolus vulgaris L.) derived from root and leaf tissue ESTs: an integration of the BMc series. BMC Plant Biol. 2011; 11: 50 PubMed Abstract | Publisher Full Text | Free Full Text

81. Bouchez D, Höfte H: Functional genomics in plants. Plant Physiol. 1998; 118(3): 725-32.

PubMed Abstract | Publisher Full Text | Free Full Text

82. Mir RR, Zaman-Allah M, Sreenivasulu N, et al.: Integrated genomics, physiology and breeding approaches for improving drought tolerance in crops. Theor Appl Genet. 2012; 125(4): 625-45.

PubMed Abstract | Publisher Full Text | Free Full Text

83. Yao LM, Wang B, Cheng LJ, et al.: Identification of key drought stress-related genes in the hyacinth bean. PLOS One. 2013; 8(3): e58108.

PubMed Abstract | Publisher Full Text | Free Full Text

84. Radwan A, Ali RMIA, Nada A, et al:: Isolation and characterization of some drought-related ESTs from barley. African J Biotechnol. 2015; 14(9): 794-810. Publisher Full Text

85. Ramalingam A, Kudapa H, Pazhamala LT, et al.: Gene Expression and Yeast Two-Hybrid Studies of 1R-MYB Transcription Factor Mediating Drought Stress Response in Chickpea (Cicer arietinum L.). Front Plant Sci. 2015; 6: 1117. PubMed Abstract | Publisher Full Text | Free Full Text

86. Deokar AA, Kondawar V, Jain PK, et al.: Comparative analysis of expressed sequence tags (ESTs) between drought-tolerant and -susceptible genotype of chickpea under terminal drought stress. BMC Plant Biol. 2011; 11: 70. PubMed Abstract | Publisher Full Text | Free Full Text

87. Varshney RK, Hiremath PJ, Lekha P, et al:: A comprehensive resource of drought- and salinity- responsive ESTs for gene discovery and marke development in chickpea (Cicer arietinum L.). BMC Genomics. 2009; 10: 523. PubMed Abstract | Publisher Full Text | Free Full Text

88. Jain $D$, Chattopadhyay $D$ : Analysis of gene expression in response to water deficit of chickpea (Cicer arietinum L.) varieties differing in drought tolerance. BMC Plant Biol. 2010; 10: 24

PubMed Abstract | Publisher Full Text | Free Full Text

89. Woldesemayat AA, Van Heusden P, Ndimba BK, et al:: An integrated and comparative approach towards identification, characterization and functional annotation of candidate genes for drought tolerance in sorghum (Sorghum bicolor (L.) Moench). BMC Genet. 2017; 18(1): 119. PubMed Abstract | Publisher Full Text | Free Full Text
90. Srinivas G, Satish K, Madhusudhana R, et al.: Exploration and mapping of microsatellite markers from subtracted drought stress ESTs in Sorghum bicolor (L.) Moench. Theor Appl Genet. 2009; 118(4): 703-17.

PubMed Abstract | Publisher Full Text

91. Nie YY, Zhang L, Wu YH, et al:: Retracted: Screening of candidate genes and fine mapping of drought tolerance quantitative trait loci on chromosome 4 in rice (Oryza sativa L.) under drought stress. Ecol Evol. 2015; 5(21): 5007-15. PubMed Abstract | Publisher Full Text | Free Full Text

92. Xia H, Zheng X, Chen L, et al.: Genetic differentiation revealed by selective loc of drought-responding EST-SSRs between upland and lowland rice in China. PLoS One. 2014; 9(10): e106352.

PubMed Abstract | Publisher Full Text | Free Full Text

93. Gorantla M, Babu PR, Reddy Lachagari VB, et al:: Identification of stressresponsive genes in an indica rice (Oryza sativa L.) using ESTs generated from drought-stressed seedlings. J Exp Bot. 2007; 58(2): 253-65.

PubMed Abstract | Publisher Full Text

94. Hadiarto T, Tran LS: Progress studies of drought-responsive genes in rice. Plant Cell Rep. 2011; 30(3): 297-310.

PubMed Abstract | Publisher Full Tex

95. Kanth BK, Kumari S, Choi SH, et al.: Generation and analysis of expressed sequence tags (ESTs) of Camelina sativa to mine drought stress-responsive genes. Biochem Biophys Res Commun. 2015; 467(1): 83-93.

PubMed Abstract | Publisher Full Text

96. Chen ZY, Guo XJ, Chen ZX, et al:: Genome-wide characterization of developmental stage- and tissue-specific transcription factors in wheat. $B M C$ Genomics. 2015; 16(1): 125

PubMed Abstract | Publisher Full Text | Free Full Text

97. Ergen NZ, Budak H: Sequencing over $\mathbf{1 3} \mathbf{0 0 0}$ expressed sequence tags from six subtractive cDNA libraries of wild and modern wheats following slow drought stress. Plant Cell Environ. 2009; 32(3): 220-36. PubMed Abstract | Publisher Full Text

98. Siddappa N, Raghu GK, Devaraj VR: Identification of Drought-Responsive Transcripts in Kodo Millet (Paspalumscrobiculatum L). Int J Innov Res Dev. 2016; 5(11)

Reference Source

99. Shivhare R, Lata C: Exploration of Genetic and Genomic Resources for Abiotic and Biotic Stress Tolerance in Pearl Millet. Front Plant Sci. 2017; 7: 2069. PubMed Abstract | Publisher Full Text | Free Full Text

100. Choudhary M, Jayanand, Padaria JC: Transcriptional profiling in pearl millet (Pennisetum glaucum L.R. Br.) for identification of differentially expressed drought responsive genes. Physiol Mol Biol Plants. 2015; 21(2): 187-96. PubMed Abstract | Publisher Full Text | Free Full Text

101. Kim YH, Jeong JC, Lee HS, et al:: Comparative characterization of sweetpotato antioxidant genes from expressed sequence tags of dehydration-treated fibrous roots under different abiotic stress conditions. Mol Biol Rep. 2013; 40(4): 2887-96. PubMed Abstract | Publisher Full Text

102. Shamloo-Dashtpagerdi R, Razi H, Ebrahimie E: Mining expressed sequence tags of rapeseed (Brassica napus L.) to predict the drought responsive regulatory network. Physiol Mol Biol Plants. 2015; 21(3): 329-40. PubMed Abstract | Publisher Full Text | Free Full Text

103. Pruthvi V, Rama N, Govind G, et al.: Expression analysis of drought stress specific genes in Peanut (Arachis hypogaea, L.). Physiol Mol Biol Plants. 2013; 19(2): $277-81$

PubMed Abstract | Publisher Full Text | Free Full Text

104. Liu M, Shi J, Lu C: Identification of stress-responsive genes in Ammopiptanthus mongolicus using ESTs generated from cold- and drought-stressed seedlings. BMC Plant Biol. 2013; 13(1): 88.

PubMed Abstract | Publisher Full Text | Free Full Text

105. Kurowska M, Daszkowska-Golec A, Gruszka D, et al.: TILLING: a shortcut in functional genomics. J Appl Genet. 2011; 52(4): 371-90. PubMed Abstract | Publisher Full Text | Free Full Text

106. Moens $\mathrm{CB}$, Donn TM, Wolf-Saxon ER, et al:: Reverse genetics in zebrafish by TILLING. Brief Funct Genomic Proteomic. 2008; 7(6): 454-9. PubMed Abstract | Publisher Full Text | Free Full Text

107. Dwivedi SL, Scheben A, Edwards D, et al:: Assessing and Exploiting Functional Diversity in Germplasm Pools to Enhance Abiotic Stress Adaptation and Yield in Cereals and Food Legumes. Front Plant Sci. 2017; 8: 1461. PubMed Abstract | Publisher Full Text | Free Full Text

108. Comai L, Henikoff S: TILLING: practical single-nucleotide mutation discovery. Plant J. 2006; 45(4): 684-94. PubMed Abstract | Publisher Full Text

109. Akpinar BA, Lucas SJ, Budak H: Genomics approaches for crop improvement against abiotic stress. ScientificWorldJournal. 2013; 2013: 361921. PubMed Abstract | Publisher Full Text | Free Full Text

110. Yu S, Liao F, Wang F, et al.: Identification of rice transcription factors associated with drought tolerance using the Ecotilling method. PLOS One. 2012; 7(2): e30765. PubMed Abstract | Publisher Full Text | Free Full Text

111. Qi X, Liu C, Song L, et al:: PaCYP78A9, a Cytochrome P450, Regulates Fruit Size in Sweet Cherry (Prunus avium L.). Front Plant Sci. 2017; 8: 2076. PubMed Abstract | Publisher Full Text | Free Full Text

112. Romay G, Bragard C: Antiviral Defenses in Plants through Genome Editing 
Front Microbiol. 2017; 8: 47.

PubMed Abstract | Publisher Full Text | Free Full Text

113. Zhao $\mathrm{Y}$, Zhang $\mathrm{C}$, Liu W, et al:: An alternative strategy for targeted gene replacement in plants using a dual-sgRNA/Cas9 design. Sci Rep. 2016; 6: 23890. PubMed Abstract | Publisher Full Text | Free Full Text

114. Shi $\mathrm{J}$, Gao $\mathrm{H}$, Wang $\mathrm{H}$, et al.: ARGOS8 variants generated by CRISPR-Cas 9 improve maize grain yield under field drought stress conditions. Plant Biotechnol J. 2017; 15(2): 207-16. PubMed Abstract | Publisher Full Text | Free Full Text

115. Sun $Y$, Zhang $X$, Wu $C$, et al.: Engineering Herbicide-Resistant Rice Plants through CRISPR/Cas9-Mediated Homologous Recombination of Acetolactate Synthase. Mol Plant. 2016; 9(4): 628-631. PubMed Abstract | Publisher Full Text

116. Cardi T, D'Agostino N, Tripodi P: Genetic Transformation and Genomic Resources for Next-Generation Precise Genome Engineering in Vegetable Crops. Front Plant Sci. 2017; 8: 241. PubMed Abstract | Publisher Full Text | Free Full Text

117. Arora L, Narula A: Gene Editing and Crop Improvement Using CRISPR-Cas9 System. Front Plant Sci. 2017; 8: 1932. PubMed Abstract | Publisher Full Text | Free Full Text

118. Zhang K, Raboanatahiry N, Zhu B, et al.: Progress in Genome Editing Technology and Its Application in Plants. Front Plant Sci. 2017; 8: 177 PubMed Abstract | Publisher Full Text | Free Full Text

119. Cao HX, Wang W, Le HT, et al.: The Power of CRISPR-Cas9-Induced Genome Editing to Speed Up Plant Breeding. Int J Genomics. 2016; 2016: 5078796. PubMed Abstract | Publisher Full Text | Free Full Text

120. Noman A, Aqeel M, He S: CRISPR-Cas9: Tool for Qualitative and Quantitative Plant Genome Editing. Front Plant Sci. 2016; 7: 1740. PublMed Abstract | Publisher Full Text | Free Full Text

121. Li P, Li YJ, Zhang FJ, et al.: The Arabidopsis UDP-glycosyltransferases UGT79B2 and UGT79B3, contribute to cold, salt and drought stress tolerance via modulating anthocyanin accumulation. Plant J. 2017; 89(1): 85-103. PubMed Abstract | Publisher Full Text

122. Chilcoat D, Liu ZB, Sander J: Use of CRISPR/Cas9 for Crop Improvement in Maize and Soybean. Prog Mol Biol Trans/ Sci. 2017; 149: 27-46. PubMed Abstract | Publisher Full Text

123. Lou D, Wang H, Liang G, et al:: OsSAPK2 Confers Abscisic Acid Sensitivity and Tolerance to Drought Stress in Rice. Front Plant Sci. 2017; 8: 993. PubMed Abstract | Publisher Full Text | Free Full Text
124. Wang L, Chen L, Zhao R, et al.: Reduced Drought Tolerance by CRISPR/Cas9Mediated SIMAPK3 Mutagenesis in Tomato Plants. J Agric Food Chem. 2017; 65(39): 8674-8682.

PubMed Abstract | Publisher Full Text

125. Xu C, Fu X, Liu R, et al:: PtoMYB170 positively regulates lignin deposition during wood formation in poplar and confers drought tolerance in transgenic Arabidopsis. Tree Physiol. 2017; 37(12): 1713-26. PubMed Abstract | Publisher Full Text

126. Kumar J, Gunapati S, Kumar J, et al.: Virus-induced gene silencing using a modified betasatellite: a potential candidate for functional genomics of crops. Arch Virol. 2014; 159(8): 2109-13. PubMed Abstract | Publisher Full Text

127. Kushwaha NK, Chakraborty S: Chilli leaf curl virus-based vector for phloemspecific silencing of endogenous genes and overexpression of foreign genes. Appl Microbiol Biotechnol. 2017; 101(5): 2121-9. PubMed Abstract | Publisher Full Text

128. Ido $\mathrm{Y}$, Nakahara KS, Uyeda I: White clover mosaic virus-induced gene silencing in pea. J Gen Plant Pathol. 2012; 78(2): 127-32. Publisher Full Text

129. Liou MR, Huang YW, Hu CC, et al: A dual gene-silencing vector system for monocot and dicot plants. Plant Biotechnol J. 2014; 12(3): 330-43. PubMed Abstract | Publisher Full Text

130. Mei Y, Zhang C, Kernodle BM, et al:: A Foxtail mosaic virus Vector for VirusInduced Gene Silencing in Maize. Plant Physiol. 2016; 171(2): 760-72. PubMed Abstract | Publisher Full Text | Free Full Text

131. Yamagishi M, Masuta $C$, Suzuki M, et al.: Peanut stunt virus-induced gene silencing in white lupin (Lupinus albus). Plant Biotechnol. 2015; 32(3): $181-91$. Publisher Full Text

132. Yang N, Wang R, Zhao Y: Revolutionize Genetic Studies and Crop Improvement with High-Throughput and Genome-Scale CRISPR/Cas9 Gene Editing Technology. Mol Plant. 2017; 10(9): 1141-1143. PubMed Abstract | Publisher Full Text | Free Full Text

133. Hussain B, Lucas SJ, Budak H: CRISPR/Cas9 in plants: at play in the genome and at work for crop improvement. Brief Funct Genomics. 2018. PubMed Abstract | Publisher Full Text

134. Gao C: The future of CRISPR technologies in agriculture. Nat Rev Mol Cell Biol. 2018; 19(5): 275-276.

PubMed Abstract | Publisher Full Text 


\section{Open Peer Review}

\section{Current Peer Review Status:}

\section{Version 1}

Reviewer Report 10 December 2018

https://doi.org/10.5256/f1000research.17024.r40635

(C) 2018 Bhardwaj P. This is an open access peer review report distributed under the terms of the Creative Commons Attribution License, which permits unrestricted use, distribution, and reproduction in any medium, provided the original work is properly cited.

\section{Pardeep Kumar Bhardwaj}

Institute of Bioresources and Sustainable Development, Sikkim Centre, Gangtok, Sikkim, India

The review entitled "Milestones achieved in response to drought stress through reverse genetic approaches" by Singh et al., presents recent advances in understanding the response of drought stress in crop plants using reverse genetic technologies. It is well known that drought stress is major concern in the era of climate change. Therefore, it is important to address the recent updates on drought stress response in crop plants to scientific communities. The review article is written and organized very well but minor points need to be taken care.

1. Authors have explained several techniques available to study the functionality of different genes involved in response to drought stress but should also include the advantages of these techniques in monocots/dicots.

2. In VIGS, authors should explain the functional analysis of $D R E B$ transcription factors using VIGS technology citing some latest references.

3. In ESTs analysis, authors should include the analysis of drought responsive ESTs generated through chemical priming studied in crop plants.

Is the topic of the review discussed comprehensively in the context of the current literature?

Yes

Are all factual statements correct and adequately supported by citations? Partly

Is the review written in accessible language?

Yes

Are the conclusions drawn appropriate in the context of the current research literature? Yes 
Competing Interests: No competing interests were disclosed.

Reviewer Expertise: Plant Molecular Biology

I confirm that I have read this submission and believe that I have an appropriate level of expertise to confirm that it is of an acceptable scientific standard.

Reviewer Report 31 October 2018

https://doi.org/10.5256/f1000research.17024.r38198

(C) 2018 Mani E. This is an open access peer review report distributed under the terms of the Creative Commons Attribution License, which permits unrestricted use, distribution, and reproduction in any medium, provided the original work is properly cited.

\section{Elangovan Mani}

Advanta India Ltd., Hyderabad, Telangana, India

Title: Ok, it represents the article well

Abstract: Ok, it provide the central idea about the article precisely. However, authors can expand it a little more.

Keywords: Authors should arrange them alphabetically

Introduction: At the end of first paragraph, authors suggested about available transcriptomic data. I believe there they can add some references of available transcriptomes related to the topic. Overall, it has been written fine.

VIGS: Authors provided all the required information related to this technology. However, there are some bioinformatics tools, which helps in the selection of target fragment within the gene. They can add these too.

Expressed sequence tags (ESTs): Ok

TILLING: Ok

CRISPR Technology: Ok

Conclusion: Ok, Nicely written.

To summarize, the review by Singh et al. presents our current knowledge of many genes deciphered by reverse genetic technologies: VIGS, EST, TILLING and CRISPR. The tables represents ample amount of information in a well-organised way. Overall, the Review provides a useful compilation of subject matter related to addressed topic in a coherent way.

Is the topic of the review discussed comprehensively in the context of the current literature?

Partly

Are all factual statements correct and adequately supported by citations? Yes

Is the review written in accessible language? 
Yes

Are the conclusions drawn appropriate in the context of the current research literature? Yes

Competing Interests: No competing interests were disclosed.

I confirm that I have read this submission and believe that I have an appropriate level of expertise to confirm that it is of an acceptable scientific standard.

The benefits of publishing with F1000Research:

- Your article is published within days, with no editorial bias

- You can publish traditional articles, null/negative results, case reports, data notes and more

- The peer review process is transparent and collaborative

- Your article is indexed in PubMed after passing peer review

- Dedicated customer support at every stage

For pre-submission enquiries, contact research@f1000.com 